\title{
Versatile and flexible use of intellectual capital in entrepreneurial opportunity discovery
}

\author{
Vesa Puhakka \\ University of Oulu, \\ Department of Management and Entrepreneurship \\ P.O. Box 4600, 90014 University of Oulu, Finland \\ E-mail: vesa.puhakka@oulu.fi
}

\begin{abstract}
This study examined the links between intellectual capital of entrepreneurs and the strategies they use to discover business opportunities. The findings suggest that the relationship between intellectual capital and opportunity discovery is more complicated than we have thought. The results illustrated that entrepreneurs have (1) formal knowledge to competitively scan opportunities, (2) management experience to see proactively future trends and also understanding not to lean on their managerial experience too much, when new ideas should be innovated, (3) intrinsic motivation to innovate new ideas and to proactively predict the future and (4) creativity to see gaps in competitive arenas and to proactively predict future-oriented opportunities to fill these gaps. On the basis of the results versatile and flexible use of intellectual capital is important to entrepreneurs to be able to discover opportunities for new business. Intellectual capital as such is not that important but a certain combination of them because opportunity discovery is a multiform process.
\end{abstract}

Keywords: Entrepreneurship, Opportunity Discovery, Intellectual Capital, Strategy-Making 


\section{Introduction}

It could be proposed that new venture creation is the ultimate task of knowledge-based companies in the post-modern, digital economy (McGahan and Silverman, 2001; Christensen and Raynor, 2003). This constant renewal process takes place in a highly turbulent and dynamic business environment in which predicting based on earlier experiences is almost impossible (Sarasvathy, 2001). In this type of dynamic or even chaotic environment economy as a whole develops through experimentally organized business programs, i.e. new ventures (Eliasson, Johansson and Taymaz, 2004). In this process entrepreneurs take the most central role by recognizing the prominent new innovations developed by the technology system, discovering customer needs in markets, organizing resources and finance and manufacturing the created new business in economically efficient scale (Carlsson and Eliasson, 2003). In the light of above, entrepreneurial opportunity discovery as strategic behaviour is valuable to any individual or organisation, and thus important to understand more deeply.

The knowledge on entrepreneurial opportunity discovery has developed during the last decade significantly (see Ardichvili, Cardozo and Ray, 2003; Alvarez and Barney, 2007). A manifestation of this is the book by Shane (2003), who combines the recent knowledge on the information processing view of opportunity discovery. Nevertheless, opportunity discovery literature has many gaps leaving a lot of possibilities for contribution (Chandler, DeTienne and Lyon, 2003). For example, in spite of the significance of opportunity discovery, and exploitation of opportunities, researchers and practitioners do not yet understand how successful opportunities are discovered; are they recognized, discovered or created, by whom and where this takes place or how opportunities affect venture performance (see Chiasson and Saunders, 2005; Alvarez and Barney, 2007). However, we have an early understanding of what are the primary reasons for opportunity discovery (Shane and Venkataraman, 2000), what kind are the cognitive and social processes of entrepreneurs (Baron, 2004; Arenius and De Clerq, 2005), what are the main strategies for discovering opportunities (Dew, Velamuri and Venkataraman, 2003) and what are the primary difficulties concerning opportunity discovery process (Delmar and Shane, 2003).

Studies of opportunity discovery widely suggest that certain intellectual capabilities characterize those entrepreneurs who discover opportunities (Christensen, Madsen and Peterson, 1994; Hills, 1995; de Koning and Muzyka, 1996; Hills and Shrader, 1998; Erikson, 2002; Davidsson and Honig, 2003; Sternberg, 2003; Ucbasaran, Westhead and Wright, 2003; Ucbasaran, Westhead and Wright, 2008). These entrepreneurs have, based on the above studies, experience-based skills, formal knowledge and managerial experience of their domain of work. In addition, their intrinsic motivation pulls them to seek opportunities and they are able to creatively question the present business situation and create new solutions. Like Davidsson and Honig (2003) have argued, entrepreneurs involve their intellectual capital in opportunity discovery to create imaginary end-results.

In spite of the above developments, opportunity discovery itself is often seen as unidimensional concept (e.g. Shane, 2003; Arenius and de Clercq, 2005; Ucbasaran et al., 2008), although more process oriented studies have shown that it consists of several distinct lines of behaviour (Ardichvili et al., 2003; Davidsson and Honig, 2003; Delmar and Shane, 
2004). These distinct behavioural strategies, namely competitive scanning of market needs, proactive searching of future value states and innovative solution creation are inherently dissimilar kinds of economic action. For example, proactive searching is abstract imaging of possible future-states while competitive scanning is merely rational information gathering and analyzing. This presumably suggests that these different lines of entrepreneurial behaviour require different types of intellectual capital and that the relationship between intellectual capital and opportunity discovery is more complicated than we have thought (Ucbasaran et al., 2008). Consequently, we do not know how the dimensions of intellectual capital of entrepreneurs influence the different behavioural strategies they use in the opportunity discovery. The problem is that the results are scattered and there are, hence, difficulties to see what the impact of them is. Thus, it is suggested that the fragmented results of the effects of intellectual capital on opportunity discovery should be linked and the effects and use of these resources studied more rigorously.

To sum up, the object of the study is entrepreneurial opportunity discovery. The object is chosen because the renewal capacity through creation of new businesses is crucial in the knowledge economy. Organising new becomes more important than managing present and, therefore, creativity, motivation, social interaction and discovery, for example, come to the fore instead of adaptation to the existing situations. Building on these elements, the study aims at contributing to the development of empirical and theoretical knowledge of the entrepreneurial business opportunity recognition. Hence, the research question is: How different types of intellectual capital of entrepreneurs affect their different behaviours engaged with opportunity discovery. In the following is introduced the conceptual basis, developed the hypotheses, illustrated the used method, presented the results and finally drawn the conclusions of the study.

\section{Opportunity Discovery Strategies and Intellectual Capital}

In this study opportunity is a new means-ends relationship between goods, services, raw materials and organizing methods (see Shane and Venkataraman, 2000) coming into existence as a long-term profit potential based on a recognized market position, in which a venture is competitive beyond the short run and through which a venture can offer products and services that are attractive, durable and timely and add value to buyers and/or end users. Present study approaches opportunity phenomenon from the angle of opportunity discovery as strategy-making behaviour of entrepreneurs (cf. Alvarez and Barney, 2007) in which is discovered a business opportunity and turned it into economic value (Ireland, Hitt and Sirmon, 2003). The approach is based on the theory of entrepreneurial strategy-making (e.g. Miller and Friesen, 1978; Miller, 1987; Covin and Slevin, 1991; Miles and Arnold, 1991; Stewart, 1994). The theory argues that entrepreneurial strategy-making comes into existence as a strategic posture, involving a constant search for opportunities to create new business (Miles and Arnold, 1991). The theory of entrepreneurial strategy-making sees entrepreneurship as value-creation bringing value to customers and profit to entrepreneurs.

Entrepreneurship is therefore not so much about establishing a new firm, but about strategically developing, renewing and transforming businesses (see e.g. Covin and Slevin, 1991; Ireland, 2007; Kuratko and Audretsch, 2009). In the present study, entrepreneurship is about discovering an opportunity, seizing and evaluating the opportunity, accumulating the 
necessary resources, creating value for customers, collecting profits and investing the profits again in a new business opportunity (see Lumpkin and Dess, 1996). The most distinctive lines of behaviour regarding opportunity discovery are connected with competitive scanning (e.g. Christensen et al., 1994), proactive searching for future states (e.g. de Koning and Muzyka 1996) and innovative solution creation (e.g. Manimala, 1992). Entrepreneurs who discover opportunities possess the skills to intellectually see relevant information and shape it into an opportunity (Kirzner, 1979).

Becker (1975) in his seminal study suggested that human capital strongly affects quality of behaviour in business life. He defined human capital as consisting of experience-based and formal knowledge. Gimeno, Folta, Cooper and Woo (1997) widened this to embrace entrepreneurs as well. In opportunity discovery the intellectual capital of entrepreneurs consists of the capabilities to perceive and interpret business information (Ardichvili et al., 2003. These capabilities could be divided into domain knowledge, formal knowledge, management experience, intrinsic motivation and creativity (reference omitted).

First, domain knowledge is about being aware of people, information and possibilities in the particular industry. It consists of knowing competitors, suppliers and policies in the industry, knowing customers and their needs and knowing knowledge gaps in the industry (Gimeno et al., 1997). Second, formal knowledge offers entrepreneurs the knowledge that has been collected until now, which helps to analyze information more widely. Formal knowledge is grounded on formal education, formal training, technical knowledge and knowledge of theories and rules of the area (Phan and Lee, 1995; Gimeno et al., 1997). Third, management experience is experience in leading and managing people and ventures. More specifically, it could be seen as managerial positions, organizing experience, leadership experience and experiences in establishing and leading own ventures (Gimeno et al., 1997). Fourth, intrinsic motivation pulls entrepreneurs to opportunity discovery and establishing a venture because of entrepreneurship itself. Money and fame are not such important motivators as fun and independence. Thus, intrinsic motivation could be studied as internal commitment, need to do things because of themselves and aspiration to establish own businesses (Gimeno et al., 1997; Kuratko, Hornsby and Naffziger, 1997). Fifth, creativity is a general capability to interpret information into novel solutions. It is fluent, flexible, original and adaptive thinking style of entrepreneurs (Sternberg, 2003; Dimov, 2007a). In the following altogether fifteen hypotheses are formulated. The overall hypothesis is that intellectual capital increases opportunity discovery behaviour. This is to be tested through more specific hypotheses.

\section{Hypotheses of the Effects of Intellectual Capital on Opportunity Discovery Effects of intellectual capital on competitive scanning of opportunities}

Cooper (1981) already saw the knowledge of the profession to be important in scanning competition. This is based on the idea by Kirzner $(1979,1981,1997)$ that domain knowledge is needed in order to be alert to gaps in the market. Long and McMullan (1985) found that entrepreneurs use their domain knowledge to scan the competitive arena. De Koning and Muzyka (1996) proposed that the experience of entrepreneurs made them actively scan the competitive environment in order to find gaps that are big enough for profitable business but not big enough to make large companies interested. It is possible to see that one of the main issues that concern experienced entrepreneurs is to find niches in markets. Therefore, 
competitive scanning is suggestively affected positively by domain knowledge (see Fiet, Piskounov and Patel, 2005).

Kaish and Gilad (1991), again, pointed out that entrepreneurs were more aware of risk cues in markets than managers. This shows how domain knowledge, which especially entrepreneurs have, enhances competitive scanning of risks in markets. Hills and Lumpkin (1997) propose that entrepreneurs see competitive scanning to be important in opportunity discovery, and this to be affected by the level of domain knowledge. Christensen and Peterson (1990) suggest as well that domain knowledge is very important to able to understand markets and competitors in it. The above studies all propose that domain knowledge should increase competitive scanning of opportunities. Therefore, the following hypothesis is presented: Hypothesis 1a: The higher the domain knowledge of entrepreneurs, the more intense is their competitive scanning of opportunities.

The study by Kaish and Gilad (1991) suggests that formal knowledge, something that managers probably have more of than entrepreneurs, makes them to neglect market risk cues that entrepreneurs see. However, managers try to scan competition more than entrepreneurs but are somehow trapped by their formal models. Therefore, it is suggested that formal knowledge enhances competitive scanning but might also make it harder to understand it without domain knowledge. Aggressive competitive scanning of skilled entrepreneurs was also noticed by Woo et al. (1992).

Zietsma (1999) then found that formal knowledge causes entrepreneurs to neglect scanning competition because of overconfidence. This would mean that formal knowledge decreases competitive scanning because entrepreneurs rely too much on their formal knowledge. However, Hills (1995) and Hills and Lumpkin (1997) have suggested that formal knowledge might affect competitive scanning positively (see also de Koning and Muzyka 1996). Therefore, it is possible to put forth that formal knowledge enhances competitive scanning. It is argued here that formal knowledge offers cognitive tools that could be used to analyze more effectively the competitive arena and to be more ambitious and aggressive. Although the results are a bit controversial, the following hypothesis is presented: Hypothesis $1 b$ : The higher the formal knowledge of entrepreneurs, the more intense is their competitive scanning of opportunities.

Thakur (1999) has found that managerial capabilities are needed to be able to scan the competitive arena. Managerial capabilities could be seen as management experience. Hills, Lumpkin and Singh (1997) and Hills and Shrader (1998) also point out that prior experience of entrepreneurship and/or management is needed in competitive scanning. De Koning and Muzyka (1996), again, found that experienced entrepreneurs put a lot of effort into understanding markets. The scanning of markets and profitable gaps in them was the ground of entrepreneurs' whole opportunity discovery process. Management experience has created in them a sense that by knowing the market success could be confirmed (Cassar, 2006).

The positive effect of management experience on competitive scanning is also supported by the study by Christensen et al. (1994). They argue that strategic thinking skills, which develop through constant practicing and trial and error, are the core resources based on which competition can be understood (see also Corbett, 2005). Here it is suggested that strategic thinking skills are the core of management experience. The above results propose that 
management experience guides entrepreneurs especially to mind competitive arena. Therefore, the following hypothesis is presented: Hypothesis 1c: The higher the management experience of entrepreneurs, the more intense is their competitive scanning of opportunities.

Herron and Sapienza (1992) have proposed that higher intrinsic motivation would lead to higher competitive scanning. Gaglio and Taub (1992) showed that entrepreneurs, who relied on their own opinions and decisions, i.e. intrinsic motivation, put more effort into trying to understand competition. Also Manimala $(1992,1996)$ came to the same conclusions. He pointed out that high-innovative entrepreneurs, who were intrinsically motivated, were scanning competition intensively. De Koning and Muzyka (1996) showed how entrepreneurs enjoyed the scanning of the competitive arena. This illustrates clearly how intrinsic motivation enhances competitive scanning, Christensen et al. (1994) emphasized that competitive scanning is one of the main areas of behaviour in opportunity discovery and it to be incremental learning process, in which problems are turned into possibilities.

Here it is suggested that constant learning and problem solving requires a lot of intrinsic motivation because it is cognitively demanding to be alert all the time. In line with this, Hills and Lumpkin (1997) showed how entrepreneurs were internally eager to scan competition suggesting that intrinsic motivation would increase competitive scanning. On the basis of the above, the following hypothesis is presented: Hypothesis 1d: The higher the intrinsic motivation of entrepreneurs, the more intense is their competitive scanning of opportunities.

Finally, Kirzner (1997) has argued for the idea that it needs creativity to be alert to market gaps (see also Corbett, 2007). Hills, Shrader and Lumpkin (1999) studied opportunity discovery and noticed that competitive scanning requires skills to creatively question the market situation. This is also supported by Hills and Lumpkin (1997), Hills et al. (1997) and Hills and Shrader (1998), according to whom creativity plays an important role in searching for knowledge of a competitive arena. De Koning and Muzyka (1996) also pointed out that successful entrepreneurs use their creativity to find market niches. In addition, Sigrist (1999) and Shane and Venkataraman (2000) argue about the skills to link information into new solutions invisible to others, i.e. creativity to give possibilities of flexibly learning from customers, intuitively read market dynamism and impulsively react to situations. Therefore, the following hypothesis is presented: Hypothesis 1e: The higher the creativity of entrepreneurs, the more intense is their competitive scanning of opportunities.

\section{Effects of intellectual capital on proactive searching of opportunities}

According to Cooper (1981), the knowledge of domain gives tools to search for future changes in a business environment. Peterson (1985), as well, underlines how experience is used to proactively position a venture in a business arena. Domain knowledge, therefore, creates a kind of cognitive map, which could be used to search for the best routes to future customers (Fiet et al., 2005). Therefore, entrepreneurs use their domain knowledge to build a vision of what will happen. It is probable that those who don't know the domain see the future just when it is already the reality. Hills (1995) also indicates this, suggesting that experience in the domain lead entrepreneurs rather to vision of what will happen than to what has happened. Rea, Maggiore and Allegro (1999) propose that entrepreneurs construct visions of the future without exact information but merely on the basis of their experience. This is line with the studies by Baron (1998; 2004), who revealed that entrepreneurs easily fix their 
eye on the future because their prior knowledge structures, experiences, advise them to do that.

Last, the importance of domain knowledge is clearly shown by Martello (1994). He argues that opportunity discovery is serendipitous future scanning, in which previous experiences in the domain have a central role. Opportunities are often found, according to Martello (1994), almost accidentally after serious working in the field, but not necessarily after deliberately searching for an opportunity, and unconscious scanning of information cues. This understanding of the cues of future possibilities requires a lot of experience in the field. Hereafter, the following hypothesis is presented: Hypothesis 2a: The higher the domain knowledge of entrepreneurs, the more intense is their proactive searching of opportunities.

Christensen and Peterson (1990) showed that what is needed besides domain knowledge is also general alertness, i.e. formal knowledge, to be capable to strategic thinking. This contains the idea that formal knowledge is needed to strategically see the future. Hills and Lumpkin (1997) found that entrepreneurs were able to transfer general opportunity discovery skills to different types of situations than the domain they were familiar with. This also implies that formal and more general skills to use knowledge are used to proactively search for future business opportunities. Entrepreneurs don't stay in the familiar area, but also search for unfamiliar arenas using their formal knowledge.

Most importantly, Zietsma (1999) indicated that higher technical education significantly increased the likelihood of deliberate future scanning of opportunities. Rea et al. (1999) argued that formal education is important in developing needed managerial skills, which are used to vision the future. Herron and Sapienza (1992), as well, stress that formal skills affect positively proactive opportunity searching. Hypothesis $2 b$ : The higher the formal knowledge of entrepreneurs, the more intense is their proactive searching of opportunities.

Hills et al. (1997) and Hills and Shrader (1998) indicated that behaviour that characterized opportunity discovery was proactive searching for future possibilities. What they also found was that these entrepreneurs had experience in entrepreneurship and management of their own and others' ventures. On the basis of this, it is possible to suggest that management experience should enhance proactive searching of opportunities (Corbett, 2005). This is supported by the study by de Koning and Muzyka (1996), in which they studied already experienced entrepreneurs' opportunity discovery, and came to the conclusion that they have a skill to vision the future. Also Kaish and Gilad (1991) and Cassar (2006) showed how experienced entrepreneurs were able to interpret the information cues. Therefore, the following hypothesis is presented: Hypothesis $2 c$ : The higher the management experience of entrepreneurs, the more intense is their proactive searching of opportunities.

Baron's (1998) study was interesting in respect of the motivational background of entrepreneurs searching for opportunities (see also Baron, 2004). It showed that entrepreneurs were highly intrinsically motivated to search for future possibilities (see Cardona, Zietsma, Saparitoc, Matherned and Davise, 2005). They weren’t so much concerned with the past or even the present - what has happened has happened. Therefore, intrinsic motivation for entrepreneurship turn they attention to the future and proactive behaviour (see Baron, 2004).

In line with this is the study by Martello (1994). He suggests that entrepreneurs are highly 
motivated to work in the field they are interested in. At the same time they all the time scan information cues in order to recognize future possibilities. Therefore, their passion, i.e. intrinsic motivation, pulls them to proactively search at the same time as they are working at other things in the field. Manimala (1992) indicated that innovative entrepreneurs were intrinsically motivated and proactive in their scanning. Also based on the study by Hills (1995) it is possible to see how passionate interest in the domain makes entrepreneurs search for proactive ideas. Therefore, the following hypothesis is presented: Hypothesis 2d: The higher the intrinsic motivation of entrepreneurs, the more intense is their proactive searching of opportunities.

Gilad (1984) stated that creativity is needed to proactively transform information into appropriate and unusual solutions. According to Gilad (1984), creativity is the main cognitive vehicle of human beings in proactive behaviour. Other studies have also quite generally seen creativity to be important in opportunity discovery (Alvarez and Barney, 2007; Corbett, 2007; Dimov, 2007a, 2007b)). Hills (1995) and Hills et al. (1999) also propose that creativity enhances future scanning of possibilities. On the basis of a study by Christensen et al. (1994), it is possible to say that the capability to turn problems into possibilities is linked to the ability to strategically think of the future of the business. De Koning and Muzyka (1996) also suggest that creativity supports proactive searching of opportunities. Therefore, the following hypothesis is presented: Hypothesis 2e: The higher the creativity of entrepreneurs, the more intense is their proactive searching of opportunities.

\section{Effects of intellectual capital on innovative solution creation}

Hills et al. (1999) argue that innovative solution creation is at the core of opportunity discovery. On the other hand, they propose that domain knowledge affects opportunity discovery positively. Further, Hills (1995) showed that successful entrepreneurs, who were experienced in their field, innovated ideas actively. Manimala (1992, 1996) studied high- and low-innovative entrepreneurs. He found that a more innovative entrepreneur knew customers, dealers, suppliers and others dealing with the products and services in that industry better. Therefore, domain knowledge enhanced innovative solution creation (see also Fiet et al., 2005. The following hypothesis is presented: Hypothesis 3a: The higher the domain knowledge of entrepreneurs, the more intense is their innovative solution creation in opportunity discovery.

Christensen and Peterson (1990) came to the conclusion that formal knowledge of a market or a technology might be the source of innovative venture ideas. This suggests that formal knowledge should support innovative solution creation so that new ideas are possible to construct. Gaglio and Taub (1992) pointed out, when studying opportunity discovery of entrepreneurs and managers' that managers were more skilled innovators. This suggests that formal knowledge, which is suggestively higher among managers, affects innovative solution creation positively. Zietsma (1999) also found that both high-tech entrepreneurs (high formal knowledge) and managers (high formal knowledge) were good at innovating ideas.

This doesn't imply that less educated persons are poor at innovating but it suggests, at least, that high formal knowledge might cause intense innovative solution creation. The reason for this might be, as Shane and Venkataraman (2000) propose, that some are better at processing information than others. This skill to process information is probably created to a large extent 
by formal education. Formal education provides general thinking skills, which could be used in many kinds of situations (Mayer, 1992). Therefore, the following hypothesis is presented: Hypothesis 3b: The higher the formal knowledge of entrepreneurs, the more intense is their innovative solution creation in opportunity discovery.

Thakur (1999) proposed based on nearly fifty case studies that without managerial capabilities it would be difficult to innovate solutions that are useful and appropriate. Hills (1995), Hills et al. (1997) and Hills and Shrader (1998) also argue innovativeness to be usual among experienced entrepreneurs. They studied entrepreneurs with prior entrepreneurial and/or managerial experience and found that they spend a lot of time playing with ideas. Therefore, the following hypothesis is presented: Hypothesis 4c: The higher the management experience of entrepreneurs, the more intense is their innovative solution creation in opportunity discovery.

Gaglio and Taub (1992) found that entrepreneurs were intrinsically motivated in their actions. They showed also that innovative solution creation was one of the central actions in opportunity discovery. Therefore, innovative solution creation should be positively influenced by intrinsic motivation. Further, Manimala (1992) came to the conclusion that innovative entrepreneurs were intrinsically motivated, i.e., intrinsic motivation increased high-innovative solution creation. The results reached by Hills (1995) suggest that internal motivation should enhance innovative solution creation. It is also interesting that internal motivation to work with other people enhances innovative solution creation (Cardona et al., 2005). Therefore, the following hypothesis is presented: Hypothesis $4 \mathrm{~d}$ : The higher the intrinsic motivation of entrepreneurs, the more intense is their innovative solution creation in opportunity discovery.

Gaglio and Taub (1992) proposed as well that creativity should be used to innovate ideas (see also Dimov, 2007a, 2007b). Hills (1995) studied opportunity discovery of successful entrepreneurs and found out that they frequently try to innovate ideas. On the other hand, the entrepreneurs said that they use creative thinking as a tool for this. In the studies of Hills and Lumpkin (1997), Hills et al. (1997) and Hills and Shrader (1998) entrepreneurs also told the authors that they frequently use creativity in order to play with new ideas, i.e., to innovate. De Koning and Muzyka also (1996) pointed out that entrepreneurs use their personal creativity to innovate new opportunities. Therefore, the following hypothesis is presented: Hypothesis 4e: The higher the creativity of entrepreneurs, the more intense is their innovative solution creation in opportunity discovery.

\section{Method}

The sample under study consists of new firms established in one year in Finland, in three regions of Finland and in the industry sectors of metal and information and communication technology (ICT). The sample was drawn from Trade Register of Finland. Trade Register offers such information as contact information, contact person, name of the firm, description of the business of the firm, year and month of registration and location. Using this information the sample was possible to draw from the database. Thus, it was possible to locate the contact information of all 223 firms.

The questionnaire was designed based on the review of the literature. The items were 
translated from English to Finnish and then again back to English. The items were measured on a seven-point Likert-scale, where the choices ranged from $1=$ strongly disagree to $7=$ strongly agree. As a pilot test, three entrepreneurs from firms representing the population filled out the questionnaire. The main effect was that wording was changed to simpler and more exact. The three entrepreneurs in the pilot test were excluded from the sample.

The questionnaire was sent to the founders of the sampled companies. After one week, these entrepreneurs were contacted by phone, e-mail or fax to remind them of the questionnaire. This procedure resulted in 101 usable questionnaires and a response rate of $47.4 \%$. All the questionnaires were checked in order to find missing values. Only seven items in five questionnaires were missing. The entrepreneurs were contacted by e-mail and all the seven missing values were obtained.

In order to test possible non-response bias, respondents and non-respondents were compared in respect of location and industry. Chi-square analyses presented in Table 1 show that in terms of location there is no statistical difference between respondents and non-respondents. In terms of industry there is no statistical difference either. Thus, respondents reflect reliably the population in respect of location and industry.

Table 1. Comparison of respondents and non-respondents in terms of location and industry

\begin{tabular}{lllll}
\hline & Value & $\mathrm{df}$ & $\begin{array}{l}\text { Significance } \\
\text { (two-tailed) }\end{array}$ \\
\hline Location & Pearson chi-square & 3.20 & 2 & .21 \\
Industry & Pearson chi-square & .237 & 1 & .63 \\
\hline
\end{tabular}

\section{N 223 Missing 0}

Further, late response bias was tested by comparing early respondents with late respondents. First, early and late respondents were studied in terms of gender of founders, location of firms and industry of firms. Chi-square analysis didn't show any significant differences (see Table 2). Early and late respondents were, in addition, compared in terms of age of founders, initial capital, number of employees in the beginning and radius of business. The results of one-way ANOVA analyses didn't show any significant differences (see Table 3). On the basis of the above results of late response analyses, it is possible to say that the data representatively illustrates the sample.

Table 2. Comparison of early (first 51) respondents and late (last 50) respondents in terms of sex of founders, location of firms and industry of firms

\begin{tabular}{llll}
\hline & Chi-square value & df & $\begin{array}{l}\text { Significance } \\
\text { (two-tailed) }\end{array}$ \\
\hline Gender of founders & .40 & 1 & .53 \\
Location of firms & .20 & 2 & .90 \\
Industry of firms & .32 & 2 & .74 \\
\hline
\end{tabular}

N 101 Missing 0 
Table 3. Comparison of early (first 51) respondents and late (last 50) respondents in terms of age of founders, initial capital of firms, number of employees in the beginning and radius of business in the beginning

\begin{tabular}{lll}
\hline & F value & Significance \\
\hline Age of founders & .53 & .47 \\
Initial capital of firms & .63 & .43 \\
Number of employees & .65 & .42 \\
Radius of business & .18 & .68 \\
\hline
\end{tabular}

\section{N 101 Missing 0}

In the data analysis was used multiple regression analysis. The most used method for estimating the regression equation is the least square method. The least square method minimizes the sum of the squared residual vertical distances between the observed data points and the regression line. This could be seen so that parameter estimates are chosen so that residuals are as small as possible. This study uses the least square method. In regression analysis the statistical significance of coefficient $b_{k}$ is tested by using the t-test. The t-test tests how many standard errors the coefficient is from zero. If the result of t-test is that the p-value of the coefficient is below 0.05, the coefficient is significant. Present study used standardized regression coefficients (beta) as indicators of explanatory power because the variables don't have natural scales (e.g. years or kilograms) and because it is desirable to compare the explanatory power of different coefficients. Standardized beta values are relative values making the comparison of effects possible. It is calculated for each independent variable so that the regression coefficient is multiplied by the ratio of the standard deviation of the independent variable to the standard deviation of the dependent variable. The beta values vary between zero and one, and the closer the value is to one, the more explanatory power the independent variable has.

Factor analysis and the Cronbach alpha reliability coefficient were used to confirm the unidimensionality and inter-item reliability of constructs. Only those variables that had factor loadings of .60 or higher on a primary dimension and .40 or lower on any other dimension were accepted. Whenever it was possible, already reliable measures of other studies were used. The constructs were chosen based on the literature review.

Dependent variables of the study were competitive scanning of opportunities, proactive searching of opportunities and innovative solution creation in opportunity discovery. . Measurement items, sources and factor loadings of opportunity discovery are presented in Table 4. Competitive scanning of opportunities was measured in the questionnaire by using five items (Miller, 1987). The first asked if the entrepreneurs had a strong proclivity for high-return projects even though they involved high risk, the second asked whether the entrepreneurs were predisposed to bold and wide-ranging actions in opportunity searching, and the third asked whether the entrepreneurs tried to find original ideas. The fourth item asked if the entrepreneurs liked to discuss with other people in order to recognize an opportunity and the fifth item if they used experts to help them in the opportunity recognition. The factor loadings of the items were all above .60. The Cronbach alpha coefficient for this 
construct was .85.

Proactive searching was measured using four items (Miller, 1987). The first asked whether the entrepreneurs did long-term planning, the second asked whether the entrepreneurs tried to find an opportunity with high newness-value. The third item asked whether the entrepreneurs purposefully spent time on creativity and fourth if they outlined things in a few years perspective when they tried to recognize an opportunity. The range of factor loadings was from .60 to .90 . The Cronbach alpha coefficient was .75. 
Table 4. Measurement items, sources and factor loadings of opportunity discovery.

\begin{tabular}{lll}
\hline Items & Sources & $\begin{array}{l}\text { Factor } \\
\text { loadings }\end{array}$ \\
\hline
\end{tabular}

\section{Competitive scanning of opportunities}

I had a strong proclivity for high-return projects, despite high risk, Miller 1987

rather than for low-profit, low-risk projects.

I went actively in for bold, wide-ranging actions in opportunity Miller $1987 \quad 86$ searching rather than accepted too cautious and thoroughly studied

ways of doing things.

I tried very actively to recognize an opportunity that would beat Miller 1987 competitors rather than let all flowers bloom.

I liked a lot to negotiate and discuss with other people in order to Miller 1987 recognize an opportunity.

I used often experts to help me in opportunity recognition.

Miller 1987

Proactive searching of opportunities

I planned far ahead (for example 3 years) already from the phase of Miller 1987 opportunity recognition.

I tried very actively to sketch that kind of an opportunity that would be Miller 1987

clearly ahead in newness of products of competitors.

I purposefully spent time on creativity when I tried to recognize an Hart 1992 opportunity.

I outlined things in a few years perspective when I tried to recognize an Miller 1987 opportunity.

\section{Innovative solution creation of opportunities}

Recognizing of opportunities was more about trial and error with ideas Miller 1987 than carefully planned activity.

I played with and tried a lot of different and new types of ideas to the Miller 1987 industry in order to recognize an opportunity.

I didn’t plan that carefully my opportunity recognition but it merely just Miller 1987 happened and developed in time by itself.

I tried actively to recognize an opportunity that would be growth Miller 1987 oriented and innovative rather than thoroughly tried and secure idea

Principal component analysis using VARIMAX rotation. Item loadings not less than .60 on a primary dimension and not more than .40 on any other dimension were retained. 


\section{Macrothink}

Journal of Management Research

ISSN 1941-899X

2010, Vol. 2, No. 1: E3

Innovative solution creation was measured through five items (Miller, 1987). First, it was asked whether the searching was about learning by trying new ideas and, second, whether entrepreneurs played with many different things. Third item asked if opportunity recognition was not planned carefully but merely just happened and developed in time by itself. Fourth item asked if entrepreneurs tried to find original and new type of ideas in order to recognize an opportunity. Fifth item asked if entrepreneurs tried actively to recognize an opportunity that would be growth oriented and innovative rather than thoroughly tried and secure. The factor loadings were above .60. The Cronbach alpha coefficient was .61

Independent variables were domain knowledge, formal knowledge, management experience, intrinsic motivation and creativity. Domain knowledge was measured by using three items. Measurement items, sources and factor loadings of intellectual capital are presented in Table 5.

The first asked how similar recent customers are to the customers of the former employers of the entrepreneurs. The second item asked how similar the products are to the former employers' products. Last similarity of suppliers is asked about. These questions are applied from the study by Gimeno et al. (1997). The factor loadings of the items were above .70 . The Cronbach alpha coefficient was .78.

Two items measured formal knowledge. These are education of entrepreneurs and technical skills of entrepreneurs. Phan and Lee (1995) and Gimeno et al. (1997) indicated these items to well reflect the formal knowledge of entrepreneurs. The factor loadings of the items were .83 and .88. The Cronbach alpha coefficient for this construct was .68.

Management experience was measured by using two items inquiring experience of managerial actions and entrepreneurial actions. The questions were adopted from Gimeno et al. (1997). The factor loadings of the items were .88. The Cronbach alpha coefficient for this construct was .80 . 
Table 5. Measurement items, sources and factor loadings of intellectual capital.

\begin{tabular}{lll}
\hline Items & Sources & Factor \\
& & loadings
\end{tabular}

Domain knowledge

How close the customers of your company were to customers Gimeno et al. 1997

of your prior employees*?

How close the products of your company were to products of Gimeno et al. $1997 \quad 82$

you prior employees?

How close the suppliers of your company were to suppliers of Gimeno et al. $1997 \quad$.71 your prior employees*?

Formal knowledge

Which one of the followings is closest to your formal degree of Phan and Lee 1995; .88 education at the time of you established your company? Gimeno et al. 1997

What were your technical capabilities in the line of business in Phan and Lee 1995

which your company was at the moment of establishment?

\section{Management experience}

How much did you have entrepreneurship experience at the Gimeno et al. $1997 \quad$ 88 moment of your company's establishment?

How much did you have management experience at the Gimeno et al. $1997 \quad$ 88 moment of your company's establishment?

How much did you have work experience from your company's Intrinsic motivation

I wanted to show that I can do it. Kuratko et al. $1997 \quad$.89

I wanted to do that kind of work I like. Kuratko et al. $1997 \quad$.87

I wanted to do work that offers personal challenges.

Gimeno et al. 1997; .78

Kuratko et al. 1997

I wanted to have appreciation. Kuratko et al. $1997 \quad$.77

I wanted to develop as an individual.

Kuratko et al. 1997

\section{Creativity}

I'm good at questioning normally used ways of doing things.

I'm sensitive to seeing problems that others don't see.

Kivikko 1977

.89

Kivikko 1977

I search for new solutions even when they are not needed.

Kivikko 1977

I find special and surprising solutions to problems.

Kivikko 1977

Principal component analysis using VARIMAX rotation. Item loadings not less than 0.6 on a primary dimension and not more than 0.4 on any other dimension were retained.

Five items measured intrinsic motivation. The first item asked how strongly entrepreneurs wanted to show that they are able do it. The second item asked if they felt the situation as a challenge. The third question inquired how important it was that they were able to do work they enjoy. Fourth items asked how much they wanted to be respected by others. The fifth item inquired the need to develop as a human being. These questions were adopted from the studies by Gimeno et al. (1997) and Kuratko, Hornsby and Naffziger (1997). The factor 
loadings of the items were all above .77 and the Cronbach alpha coefficient .88 .

Last, five items measured creativity. First asked how good the entrepreneur is when it comes to questioning normal ways of doings things. Second asked how sensitive (s)he is to seeing the kind of problems that others cannot see. The third item asked how often new solutions come into his/her mind. The fourth item asked originality of ideas. The last item asked if (s)he has plenty of ideas. The questions were adopted from the study by Kivikko (1977). The factor loadings of the items were above .71. The Cronbach alpha coefficient for this construct was .86.

Reliability of the empirical data was evaluated by using several procedures. The empirical data was collected from one person only. (S)he was the original discoverer of the opportunity. This approach was used as it was required that the informant should know the whole process of the opportunity discovery. However, this causes possibilities of bias in the data, as it is based on one person's views only. Some steps were used to ensure that the data should nevertheless be reliable. First, the questionnaire was carefully designed with several rounds of revisions and a pilot test. In this way it was ensured that informants would understand the questions. Second, as concrete questions and statements as possible were used. Also only Likert-scale questions were used in order to make sure that the questionnaire would be easy and clear to fill out. Third, it was checked how many values were missing in the answers of the informants. This ensured that there weren’t any missing values.

To assure face validity in this study are used only such constructs as are used in other similar types of studies. The used constructs are based on the careful review of literature. When content validity is taken care of, it should begin with a review of the literature, through which is analyzed how others have used the construct; second, the content should be stratified into the most important facets; and the method should be pretested. This study used these guidelines in designing the constructs and the survey-instrument. Construct validity is about how a method is related to other methods within a system of theoretical relationships. As was indicated the constructs of the study were unidimensional. Predictive validity measures how well the methods can yield results that are in line with the suggested theoretical model. The results section show that the suggested model works reasonably well.

\section{Results}

In order to test hypotheses, regression analyses were carried out. The analyses tested the effects of intellectual capital variables on opportunity recognition behaviour variables. The results are indicated in Table 6. The values of the Durbin-Watson test were close to 2, indicating that problems with multicollinearity shouldn't exist. Tolerance- and VIF-values were also examined in order to study multicollinearity. All the tolerance values were above 0.10 and the VIF-values below 10 . These results indicate that multicollinearity should not cause problems in the regression analyses.

Hypotheses 1a-1e: effects of intellectual capital on competitive scanning of opportunities. On the basis of Hypothesis 1a domain knowledge should increase competitive scanning as it gives cognitive knowledge structures to understand a competitive arena. The results show the 
relationship to be not significant and thus Hypothesis 1a is rejected. Hypothesis $1 \mathrm{~b}$ claimed that formal knowledge increases competitive scanning as formal knowledge gives an understanding that the competitive arena is important to know and that formal knowledge is not enough but also empirical perceptions are needed. Regression analysis supports Hypothesis 1b. Management experience was also hypothesized to have a positive influence on competitive scanning. Hypothesis 1c, however, doesn't receive support. Hypothesis 1d proposes that intrinsic motivation has a positive effect on competitive scanning as it requires commitment and interest to analyze the situation. The relationship is negative but not significant, and thus, Hypothesis 1d is rejected. Last, Hypothesis 1e claims that creativity should enhance competitive scanning as creative entrepreneurs want to question the competition and create a new competitive situation by knowing as well as possible the competitive logic. Regression analysis supports Hypothesis 1e. The effects of control variables were also tested and the age of founders had a significant negative effect and ICT-industry also a significant negative effect on competitive scanning.

Hypotheses 2a-2e: effects of intellectual capital on proactive searching of opportunities. Hypothesis 2a set forth that domain knowledge increases proactive scanning of possible futures as it offers cognitive tools to interpret the information cues. Regression analysis shows that the relationship is not significant, and thus, Hypothesis 2a is not supported. Formal knowledge was also hypothesized to have a positive effect. This is based on the notion that when more people are educated more fluently they use experiences of one area in other areas. This is not the case based on the results and Hypothesis $2 \mathrm{~b}$ is rejected. Hypothesis 2c suggests that management experience increases proactive behaviour as managerial and entrepreneurial experiences have created cognitive skills to interpret the possible future. The results support Hypothesis 2c showing that entrepreneurs having management experience don't have to concentrate so much on understanding the present situation but are able to set free their efforts to vision the future. Intrinsic motivation should as well enhance proactive searching. This was hypothesized as intrinsic motivation is seen to set free "journeys to the future”. Hypothesis 2d receives support. Hypothesis 2e claims creativity to support proactive searching as creativity is the main individual skill to see situations differently, i.e., to see the future. Regression analysis offers support for Hypothesis 2e. 
Table 6. Regression tests of hypotheses

\begin{tabular}{llll}
\hline Dependent variables & $\begin{array}{l}\text { Competitive } \\
\text { scanning } \\
\text { of opportunities }\end{array}$ & $\begin{array}{l}\text { Proactive } \\
\text { of opportunities }\end{array}$ & $\begin{array}{l}\text { searching } \\
\text { opportunities }\end{array}$ \\
\hline Independent variables & & & \\
Domain knowledge & -.12 & .06 & -.11 \\
Formal knowledge & $.27^{* *}$ & -.03 & .04 \\
Management experience & .11 & $.25^{*}$ & $-.23^{*}$ \\
Intrinsic motivation & -.05 & $.28^{* *}$ & $.39^{* * *}$ \\
Creativity & $.19^{*}$ & $.23^{*}$ & .14 \\
Control variables & & & \\
Age of founders & $-.37^{* *}$ & .13 & -.01 \\
Initial capital & .09 & -.26 & -.16 \\
Number of employees & .22 & .21 & .08 \\
Radius of business & .04 & .15 & .00 \\
ICT-technology & $-.30^{* * *}$ & .00 & -.20 \\
Metal industry & .00 & .00 & .00 \\
Province of Jyväskylä & .00 & .00 & .00 \\
Province of Oulu & .06 & -.09 & .06 \\
Province of Vaasa & $.23^{*}$ & -.05 & $.26 *$ \\
$\mathrm{R}^{2}$ & .40 & .32 & .29 \\
Adjusted R & .31 & .22 & .18 \\
F & $4.52^{* * *}$ & $3.26^{* * *}$ & $2.77^{*}$ \\
Durbin-Watson & 2.05 & 2.20 & 1.81 \\
\hline
\end{tabular}

Coefficients are standardized beta weights.

$* * * \mathrm{p} \leq .001, * * \quad \mathrm{p} \leq .01, * \mathrm{p} \leq .05 ;$ one tailed tests.

Hypotheses 3a-3e: effects of intellectual capital on innovative solution creation in opportunity discovery. Hypothesis 3a proposed that domain knowledge should have a positive effect on innovative solution creation because prior knowledge helps entrepreneurs to cognitively play with issues in the field. Regression analysis shows, however, that the relationship is not significant. Formal knowledge was in the Hypothesis 3b suggested to have a positive influence on innovative solution creation as formal knowledge gives knowledge structures that enhance cognitive skills of seeing new, innovative solutions. The relationship was positive but not significant. Hypothesis $3 b$ is, thus, rejected. Hypothesis $3 c$ puts to the fore that management experience should increase innovative solution creation because managerial experiences offer important tools to innovate new kinds of solutions. The relationship is significant but instead of enhancing managerial experience restricted the thinking processes of entrepreneurs. This negative effect might be a result of cognitive barriers and heuristics that lead to overconfidence. Then, it was proposed that intrinsic motivation should increase innovative solution creation. Hypothesis 3d was strongly supported. Creativity was also hypothesized to enhance innovative solution creation. The 
relationship is not significant. Hypothesis 3e is thus rejected. Of the control variables, the province of Vaasa influenced positively and significantly innovative solution creation.

\section{Conclusions}

The purpose of this study has been to investigate business opportunity discovery. This has been done by studying the effects of intellectual capital of entrepreneurs on their opportunity discovery behaviour. The results illustrated that entrepreneurs have formal knowledge to competitively scan opportunities, management experience to see future trends and understand not to bank too much on their managerial experience when solutions should be innovated, intrinsic motivation to generate innovate solutions and to predict the future and creativity to see gaps in competitive arenas and to predict opportunities in the future for filling these gaps. Versatile and flexible use and interaction between different types of intellectual capital rather than the amount of intellectual capital seem to be important to entrepreneurs to discover business opportunities.

\section{Discussion of the results of the study}

Prior studies have strongly argued competitive scanning of opportunities to be based on domain knowledge, as it would offer the tacit knowledge of the area (Cooper 1981; Long and McMullan 1985; de Koning and Muzyka 1996; Hills and Lumpkin 1997; Kirzner 1997). However, this study revealed that formal knowledge is more important in competitive scanning than domain knowledge. The reason for this might be that knowing the business and actors there (domain knowledge) do not show where the anomalies are in the competitive arena. What is needed is also and especially formal analyzing and technical skills to see where and what kind of market gaps are going to open up.

The results also indicated that creativity of entrepreneurs is significant in competitive scanning of opportunities. This was in line with previous results (e.g. Hills et al. 1999). It is interesting that creativity is significant but domain knowledge is not. This implies that tacit knowledge, or in other words alertness to connections between pieces of information that is needed, is involved in capabilities of entrepreneurs to process information in novel ways and not in knowing the business per se. This is also suggested by the fact that management experience was not significant in competitive scanning of opportunities. This shows further that experience does not tell what kind the competitive arena is but that what is needed is ability to formally analyze it and willingness to creatively play with information to create an awareness of anomalies that are going to open.

Interesting is also that intrinsic motivation is not so important, although it is proposed that competitive scanning of opportunities is demanding emotionally (e.g. Herron and Sapienza 1992). This suggests that competitive scanning of opportunities is not fun but hard work that must be done. Because it is an unpleasant job, it is therefore possible that experienced entrepreneurs avoid it. Many times entrepreneurs even try to escape boring work and perhaps therefore also avoid competitive scanning of opportunities (see Kuratko et al. 1997). As a whole, based on the results of present study in competitive scanning of opportunities formal knowledge proposes the tools that are needed to understand the competition and creativity 
vehicles to see anomalies in this competition.

Previous studies have argued that proactive searching of opportunities requires both domain and formal knowledge (e.g. Woo et al. 1992; Christensen et al. 1994; Hills 1995). However, the results of the present study revealed that proactive searching of opportunities is not about rational analyzing of information but merely intuitive visioning of the future. The results indicated that proactive searching of opportunities is enhanced by prior management experiences, intrinsic motivation and creativity of entrepreneurs.

Proactive searching of opportunities, which is more about abstract projecting of the future than rational and "hard" analyzing of the present situation, calls for knowledge of how an industry is developing in a larger frame (Hills et al. 1997; Hills and Shrader 1998). This knowledge is dependent on managerial/entrepreneurial experiences. In other words, if you have worked as a manager and/or an entrepreneur, it is probable that you have a vision of larger trends in that business, and therefore you have also capabilities to forecast in some extent the future.

However, proactive searching of opportunities requires also strong intrinsic motivation to be able to explore the future. This is so maybe because proactive searching of opportunities is largely based on intuitions, which are possible only if an individual is really internally motivated. Intuitions are not possible to create by force or necessity (see Manimala 1992; Martello 1994; Hills 1995; Baron 1998). Creativity is also necessary to be able to link weak information cues so that an entrepreneur recognizes future developments (Gilad 1984; Hills and Shrader 1998).

Present study showed that although rational analyzing of the competitive arena and knowledge acquisition are very important in order to know what the industry stands for creative and intuitive visioning of future possibilities is the most crucial part of opportunity discovery. Therefore, it should be underlined that, when capabilities to discover business opportunities are developed, serious time and effort should be given to developing creative and intuitive capabilities as well.

The results of this study indicated further that innovative solution creation in opportunity discovery is not enhanced by level of knowledge. Instead, innovative solution creation is probably natural to all human beings and therefore it needs only intrinsic motivation to be turned on. Innovative solution creation in opportunity discovery needs strong intrinsic motivation, since it is internal, mental playing with ideas. It is impossible if an entrepreneur does not enjoy it. Innovativeness is hard to rationalize and therefore it needs a pull from inside. Therefore, this study agrees with Gaglio and Taub (1992) and Manimala (1992), who have suggested that innovative solution creation in opportunity discovery requires a strong motivational ground.

Management experience, again, decreases innovative solution creation. This points clearly how existing knowledge might hinder free play with ideas (Baron 1998). The fact that creativity does not enhance innovative solution creation further shows that although innovative solution creation is not about rational processing of information neither it is totally 
creative but has certain goals to obtain.

\section{Theoretical implications and future research on entrepreneurship}

The concept of entrepreneurship has changed drastically over the past ten years (see Eckhardt and Shane, 2003; Alvarez and Barney, 2007). Entrepreneurship was long seen as the establishing and managing of a small business or owner-management. However, entrepreneurship does not directly relate to these concepts, rather entrepreneurship is context free (Shane, 2003). Entrepreneurship is noticeable, for example, in renewal efforts of any firm in identifying new markets and technologies and creating new business (cf. Carayannis, Popescu, Sipp and Stewart, 2006). The core to entrepreneurship is discovering new opportunities for business and implementing them irrelevantly to the contexts in which they take place (Park, 2005). Entrepreneurship is creative activity, where the goal is not clear and nor is often the initial situation, instead both of these are created as one goes along (Sarasvathy, Dew, Velamuri and Venkataraman, 2003).

The latest empirical research on entrepreneurship has shown that entrepreneurship is episodic, especially in the use of resources, in the level of commitment and in risk taking (Sarason, Dean and Dillard, 2006). Entrepreneurship is also about taking affordable expenses (Sarasvathy, 2001). That means doing things in the beginning that if fail, can be endured. The gradual weaving of ambitions and goals as one goes along is also a key to entrepreneurship (Tornikoski and Newbert, 2007). An important way of accomplishing this is by building strategic partners in order to understand the market place, the customers and the technology and to create trade. Hence, it is the building of understanding with the stakeholders and convincing them of the correct direction. Entrepreneurship also seems to be about the tolerance of surprising events and seeing them as possibilities (Sarasvathy, 2004).

Entrepreneurship identifies with the opportunities of creating new ventures, which consists of ideas, beliefs and needs that evolve along the journey to the goal (Sarasvathy et al., 2003). Thus, entrepreneurship is at its strongest as its actors enter the business situation, in which there is not clear understanding what is going on, what kind of trade is desired and what it is we are pursuing (see Hjorth, 2003). It does not matter whether a new firm is born from it, trade grows or a new market is conquered. It is about a problem-solving situation where the rules, solutions and goals have to be created as one progresses. In this kind of situation the right and best solution cannot be logically derived. In this situation the core content of action is related to the possibility of creating and perceiving new business opportunities. This is the phenomenon that entrepreneurship is about and what researchers should determine (Hjorth, 2003).

On the basis of the above, entrepreneurship is a process where the mental creation and surroundings of the entrepreneur are in continuous interaction with each other. Inside this entrepreneurial space something is happening that is absorbing influences from the present business activities and that is causing chaos and irregularity as a result. This study proposes that the above-presented process of entrepreneurship is cognitively/intellectually oriented but takes place in a social context of different economic actors. Thus, we should study the social-cognitive dynamisms in order to understand entrepreneurship. 


\section{References}

Alvarez, S. and Barney, J. (2007). Discovery and creation: Alternative theories of entrepreneurial action. Strategic Entrepreneurship Journal 1, 11-26.

Ardichvili, A., Cardozo, R. and Ray, S. (2003). A theory of entrepreneurial opportunity identification and development. Journal of Business Venturing 18, 105-123.

Arenius, P. and De Clerq, D. (2005). A network-based approach on opportunity recognition. Small Business Economics 24, 249-265.

Baron, R. (1998). Cognitive mechanisms in entrepreneurship: Why and when entrepreneurs think differently than other people? Journal of Business Venturing 13, 275-294.

Baron, R. (2004). The cognitive perspective: A valuable tool for answering entrepreneurship's basic “why” questions. Journal of Business Venturing 19, 221-239.

Cardona, M., Zietsma, C., Saparitoc, P., Matherned, B. and Davise, C. (2005). A tale of passion: New insights into entrepreneurship from a parenthood metaphor. Journal of Business Venturing 20, 23-45.

Carlsson, B. and Eliasson, G. (2003). Industrial dynamics and endogenous growth. Industry and Innovation 10, 435-455.

Carayannis, E., Popescu, D., Sipp, C. and Stewart, M. (2006). Technological learning for entrepreneurial development (TL4ED) in the knowledge economy (KE): Case studies and lessons learned. Technovation, 26, 419-443.

Cassar, G (2006). Entrepreneur opportunity costs and intended venture growth. Journal of Business Venturing 21, 610-632.

Chandler, G., DeTienne, D. and Lyon, D. (2003). Outcome implications of opportunity discovery/discovery Processes. In Frontiers of entrepreneurship research, (eds) W. Bygrave, C. Brush, P. Davidsson, J. Fiet, P. Greene, R.T. Harrison, M. Lerner, G. D. Meyer, J. Sohl, and A. Zacharakis. Babson College, Wellesley, MA.

Chiasson, M. and Saunders, C. (2005). Reconciling diverse approaches to opportunity research using the structuration theory. Journal of Business Venturing 20, 747-767.

Christensen, C. and Raynor, M. (2003). Innovator's solution. Harvard University Press, Cambridge, MA.

Christensen, P.S. and Peterson, R. (1990). Opportunity identification: Mapping the sources of new venture ideas. In Frontiers of entrepreneurship research, (eds) N. Churchill, W. Bygrave, J. Hornaday, D. Muzyka, K. Vesper and W. Wetzel Jr. Babson College, Wellesley, MA.

Christensen, P.S., Madsen, O.O. and Peterson, R. (1994). Conceptualizing entrepreneurial opportunity identification. In Marketing and entrepreneurship: Research ideas and opportunities. (ed) G. Hills. Greenwood Press, Westport, CT.

Cooper, A. (1981). Strategic management: New ventures and small business. Long Range 
Planning 14, 39-45.

Corbett, A. (2005). Experiential learning within the process of opportunity identification and exploitation. Entrepreneurship Theory and Practice 29, 473-491.

Corbett A. (2007). Learning asymmetries and the discovery of entrepreneurial opportunities. Journal of Business Venturing 22, 97-118.

Covin, J. and Slevin, D. (1991). A conceptual model of entrepreneurship as firm behavior. Entrepreneurship Theory and Practice 16, 7-25.

Davidsson, P. and Honig, B. (2003). The role of social and human capital among nascent entrepreneurs. Journal of Business Venturing 18, 301-331.

Delmar, F. and Shane, S. (2004). Legitimating first: Organizing activities and the survival of the new ventures. Journal of Business Venturing 19, 385-410.

Dew, N., Velamuri, S. and Venkataraman, S. (2003). Dispersed knowledge and an entrepreneurial theory of the firm. Journal of Business Venturing 19, 659-679.

Dimov. D. (2007a). From opportunity insight to opportunity intention: The Importance of person-situation learning Match. Entrepreneurship Theory and Practice 31, 561-583.

Dimov, D. (2007b). Beyond the single-person, single-insight attribution in understanding entrepreneurial opportunities. Entrepreneurship Theory and Practice 31, 713-731.

Eckhardt, J. and Shane, S. (2003). Opportunities and entrepreneurship. Journal of Management, 29, 333-349.

Eliasson, G., Johansson, D. and Taymaz, E. (2004). Simulating the new economy. Structural Change and Economic Dynamics 15, 289-314.

Erikson, T. (2002). Entrepreneurial self-efficacy and goal setting. International Journal of Entrepreneurship and Innovation 3, 183-189.

Fiet, J., Piskounov, A. and Patel, P. (2005). Still searching (systematically) for entrepreneurial discoveries. Small Business Economics 25, 489-504.

Gaglio, C.M. and Taub, R. (1992). Entrepreneurs and opportunity discovery. In Frontiers of entrepreneurship research. (eds) N. Churchill, W. Bygrave, S. Birley, D. Muzyka, C. Wahlbin and W. Wetzel Jr. Babson College, Wellesley, MA.

Gilad, B. (1984). Entrepreneurship: The issue of creativity in the market place. Journal of Creative Behavior 18, 151-161.

Gimeno, J., Folta, T. Cooper, A. and Woo, C. (1997). Survival of the fittest? Entrepreneurial human capital and the persistence of underperforming firms. Administrative Science Quarterly 42, 750-783.

Herron, L. and Sapienza, H. (1992). The entrepreneur and the initiation of new venture launch activities. Entrepreneurship Theory and Practice 17, 49-55. 
Hills, G. (1995). Opportunity discovery by successful entrepreneurs: A pilot study. In Frontiers of entrepreneurship research. (eds) M. Hay, W. Bygrave, S. Birley, N. Churchill, R. Keeley, B. Bird and W. Wetzel, Jr. Babson College, Wellesley, MA.

Hills, G., Lumpkin, G.T. and Singh, R. (1997). Opportunity discovery: Perceptions and behaviors of entrepreneurs. In Frontiers of entrepreneurship research. (eds) N. Churchill, W. Bygrave, P. Davidsson, W. Gartner, N. Carter, P. McDougall and C. Mason. Babson College, Wellesley, MA.

Hills, G. and Shrader, R. (1998). Successful entrepreneurs' insights into opportunity discovery. In Frontiers of entrepreneurship research. (eds) P. Reynolds, W. Bygrave, N. Carter and S. Manigart. Babson College, Wellesley, MA.

Hills, G., Shrader, R. and Lumpkin, G.T. (1999). Opportunity discovery as a creative process. In Frontiers of entrepreneurship research. (eds) P. Reynolds, W. Bygrave, K. Shaver, C. Mason, S. Manigart, G.D. Meyer and H. Sapienza. Babson College, Wellesley, MA.

Hjorth, D. (2003). Rewriting entrepreneurship for a new perspective on organisational creativity. Copenhagen Business School Press, Copenhagen.

Hoch, D.J, Roeding, C.R., Purkert, G., Lindner, S.K. \& Mueller, R. (1999). Secrets of software success: Management insights from 100 software firms around the world. Boston: Harvard Business School Press.

Ireland, D. (2007). Strategy vs. entrepreneurship. Strategic Entrepreneurship Journal 1: 7-10.

Ireland, D, Hitt, M. and Sirmon, D. (2003). A model of strategic entrepreneurship: The construct and its dimensions. Journal of Management 29, 963-989.

Kaish, S. and Gilad, B. (1991). Characteristics of opportunities search of entrepreneurs versus executives: Sources, interests, and general alertness. Journal of Business Venturing 6, 45-61.

Kirzner, I. (1979). Perception, opportunity, and profit. Studies in the theory of entrepreneurship. University of Chicago Press, Chicago.

Kirzner, I. (1981). Competition and entrepreneurship. University of Chicago Press, Chicago.

Kirzner, I. (1997). Entrepreneurial discovery and the competitive market process: An Austrian approach. Journal of Economic Literature 35, 60-85.

Kivikko, L. (1977). The possibilities for development of creative behavior action. Dissertation. Helsinki University of Technology, Espoo.

Koning, A. de and Muzyka, D. (1996). The convergence of good ideas: When and how do entrepreneurial managers recognize innovative business ideas? In Frontiers of entrepreneurship research. (eds) N. Churchill, W. Bygrave, J. Butler, S. Birley, P. Davidsson, W. Gartner and P. McDougall. Babson College, Wellesley, MA.

Kuratko, D. and Audretsch, D. (2009). Strategic entrepreneurship: Exploring different perspectives of an emerging concept. Entrepreneurship Theory and Practice 33, 1-17. 
Kuratko, D., Hornsby, J. and Naffziger, D. (1997). An examination of owner's goals in sustaining entrepreneurship. Journal of Small Business Management 35, 24-33.

Long, W. and McMullan, W.E. (1984). Mapping the new venture opportunity identification process. In Frontiers of entrepreneurship research. (eds) J. Hornaday, K. Vesper, F. Tarpley and J. Timmons. Babson College, Wellesley, MA.

Lumpkin, G.T. and Dess, G. (1996). Clarifying the entrepreneurial orientation construct and linking it to performance. Academy of Management Review 21, 135-172.

Manimala, M. (1992). Entrepreneurial heuristics: A Comparison between high PI (pioneering-innovative) and low PI ventures. Journal of Business Venturing 6, 477-504.

Manimala, M. (1996). Beyond innovators and imitators: A taxonomy of entrepreneurs. Creativity and Innovation Management 5, 179-185.

Martello, W. (1994). Developing creative business insights: Serendipity and its potential in entrepreneurship. Entrepreneurship and Regional Development 6, 239-258.

Mayer, R. (1992). Thinking, problem solving, and cognition. W.H. Freeman and Company, New York.

McGahan, A. and Silverman, B. (2001). How does innovative activity change as industries mature? International Journal of Industrial Organization 19, 1141-1160.

Miles, M. and Arnold, P. (1991). The relationship between marketing orientation and entrepreneurial orientation. Entrepreneurship Theory and Practice 15, 49-55.

Miller, D. (1987). Strategy making and structure: Analysis and implications for performance. Academy of Management Journal 30, 7-32.

Miller, D. and Friesen, P. (1978). Archetypes of strategy formulation. Management Science 24, 21-933.

Park, J. (2005). Opportunity recognition and product innovation in entrepreneurial hi-tech start-ups: A new perspective and supporting case study. Technovation, 25, 739-752.

Peterson, R. (1985). Creating contexts for new ventures in stagnating environments. In Frontiers of entrepreneurship research. (eds) J. Hornaday, E. Shils, J. Timmons and K. Vesper. Babson College, Wellesley, MA.

Phan, P. and. Lee, S.H (1995). Human capital or social networks: What constrains CEO dismissals? Academy of Management Journal. Best paper proceedings.

Rea, A., Maggiore, G. and Allegro, I. (1999). From the idea to the firm: A model for the entrepreneurial process. Proceedings of the $44^{\text {th }}$ ICSB World Conference. Naples, Italy.

Sarason, Y., Dean, T. and Dillard J. (2006). Entrepreneurship as the nexus of individual and opportunity: A structuration theory. Journal of Business Venturing, 21, 286-305.

Sarasvathy, S. (2001). Causation and effectuation: Toward a theoretical shift from economic 
inevitability to entrepreneurial contingency. Academy of Management Review 26, 243-263.

Sarasvathy, S. (2004). Making it happen: Beyond theories of the firm to theories of firm design. Entrepreneurship Theory and Practice, 28, 519-531.

Sarasvathy, S., Dew, N., Velamuri, S.R. and Venkataraman, S. (2003). Three views of entrepreneurial opportunity. In Handbook of entrepreneurship research: An interdisciplinary survey and introduction. (eds.) Z. Acs and D. Audretsch. Springer, New York.

Shane, S. (2003). A general theory of entrepreneurship: The individual opportunity nexus. Edward Elgar, Cheltenham.

Shane, S. and Venkataraman, S. (2000). The promise of entrepreneurship as a field of research. Academy of Management Review 25, 217-226.

Sigrist, B. (1999). How do you recognize an entrepreneurial opportunity? Entrepreneurial opportunity discovery in a Swiss context. Dissertation. University of Zurich, Zurich.

Sternberg, R. (2003). Successful intelligence as a basis for entrepreneurship. Journal of Business Venturing 19, 189-201.

Stewart, J. (1004). Future state visioning technique at National Rubber Company. Strategy and Leadership, 22, 20-33.

Thakur, S.P. (1999). Size of investment, opportunity choice and human resources in new venture growth: Some typologies. Journal of Business Venturing 14, 283-309.

Tornikoski, E. and Newbert, S. (2007). Exploring the determinants of organizational emergence: A legitimacy perspective. Journal of Business Venturing, 22, 311-335.

Ucbasaran, D., Westhead, P. and Wright, M. (2003). Human capital based determinants of opportunity discovery. In Frontiers of entrepreneurship research. (eds) W. Bygrave, C. Brush, P. Davidsson, J. Fiet, P. Greene, R.T. Harrison, M. Lerner, G. D. Meyer, J. Sohl, and A. Zacharakis. Babson College, Wellesley, MA.

Ucbasaran, D., Westhead, P. and Wright, M. (2008). Opportunity identification and pursuit: Does an entrepreneur's human capital matter? Small Business Economics 30, 153-173.

Woo, C., Folta, T. and Cooper, A. (1992). Entrepreneurial search: The alternative theories of behaviour. In Frontiers of entrepreneurship research. (eds) N. Churchill, W. Bygrave, S. Birley, D. Muzyka, C. Wahlbin and W. Wetzel Jr. Babson College, Wellesley, MA.

Zietsma, C. (1999). Opportunity knocks - or does it hide? An examination of the role of opportunity discovery in entrepreneurship. In Frontiers of entrepreneurship research. (eds) P. Reynolds, W. Bygrave, K. Shaver, C. Mason, S. Manigart, G.D. Meyer and H. Sapienza. Wellesley, MA, Babson College. 